\title{
Comparison of the chronic effects of bendrofluazide, bumetanide and frusemide on plasma biochemical variables
}

\author{
ROGer GABRIEL \\ B.A., M.Sc., F.R.C.P.
}

\author{
Peter BAyLOR \\ M.B., M.R.C.P.
}

St Charles' Hospital, London

\begin{abstract}
Summary
Eleven plasma variables have been studied in 18 elderly patients with cardiac oedema treated with bendrofluazide, frusemide and bumetanide, using a fully balanced, cross-over trial design. Bumetanide caused the least disturbance of plasma potassium and bendrofluazide the greatest. Frusemide produced an intermediate effect. The difference between the changes in plasma potassium produced by bumetanide and bendrofluazide was significant $(P<0.02)$.
\end{abstract}

\section{Introduction}

Although loop diuretics are more effective than thiazide diuretics in the treatment of acute oedema, both types of diuretic appear to be equally effective when used in small maintenance doses (Playfair, 1975). Consequently, for maintenance treatment of heart failure, the choice of diuretic may be left to the patient, some preferring the short, predictable effect of the loop diuretics, others preferring the milder, more sustained effect of the thiazides (Watt, 1978). The 2 groups of diuretic may differ in their effects on plasma biochemical variables. In comparison with thiazide diuretics, loop diuretics are said to be less likely to produce hypokalaemia (Morgan and Davidson, 1980; Duchin and Hutcheon, 1976), hyperuricaemia (Wyngaarden and Kelly, 1978), and, possibly, disturbances in carbohydrate metabolism (Dollery, 1973). Thiazide diuretics reduce the urinary excretion of calcium, while loop diuretics, at least in the short-term, increase it (Eknoyan, Suki and Martinez-Maldonado, 1970; Pak, 1973). Differences may also occur among individual loop diuretics. Several studies have suggested that potassium excretion following bumetanide is less marked than following frusemide (Dunn et al., 1975; Ramsay et al., 1978). Differences in urate and magnesium metabolism have also been described (Davies et al., 1974; Editorial, 1975).

To investigate these reported differences, a fully balanced, cross-over study was conducted in which

Correspondence: Dr Roger Gabriel, St Charles' Hospital, London, W.10. changes in plasma biochemical variables were measured in patients given bendrofluazide, bumetanide and frusemide, each for a duration of 3 months. Such a study has not been reported previously.

\section{Patients and methods}

Eighteen Caucasian out-patients with oedema, following myocardial infarction in 10 , and cor pulmonale in 6 , were selected on the grounds that they required maintenance diuretic treatment without digoxin. There were 13 men and 5 women. The mean age was 71 years (range, 55-86). All lived in a deprived inner city area. They were in a stable condition as judged by clinical examination and by body weight before entering the trial. Seven patients had been treated previously with thiazide diuretics and 11 with loop diuretics.

During the trial, no patient received potassium supplements or potassium-sparing drugs. They were given no dietary advice. None took corticosteroid or other drugs which might have affected plasma electrolyte concentrations. Bronchodilators, $\beta$-blockers and anti-arrhythmic drugs were continued without marked change in dosage throughout the trial.

Each of the 18 patients was given 3 consecutive 3-month treatments with bendrofluazide $5 \mathrm{mg}$ (A), frusemide $40 \mathrm{mg}$ (B) or bumetanide $1 \mathrm{mg}$ (C) daily. Patients were randomly allotted to treatment with one of the following treatment orders.
A $\quad$ B $\quad$ C
A $\quad$ C $B$
B C A
B A C
C A B
C $\mathbf{B}$ A

Thus each order was given to 3 patients for a total of 9 months.

Because the patients required continuous diuretic therapy, and because the duration of an adequate 'wash-out' period applicable to all variables was unknown, there was no interruption between treatment periods. The possibility of a temporal effect 
between the 3 treatments was accounted for in the statistical analysis.

Patients were investigated one week before entering the trial, at the time of entry (time 0 ) and at monthly intervals for 9 months. On each visit to the out-patient clinic, patients were weighed under standard conditions. Non-fasting blood was taken for measurement of sodium, potassium, bicarbonate, magnesium, calcium, glucose, creatinine, urea, urate, cholesterol and triglycerides. Samples were taken between 9 a.m. and 11 a.m. on Monday mornings. In order to increase the precision of the measurements at $0,3,6$ and 9 months, 2 separate samples of blood were taken from each patient. The mean of duplicates was used in subsequent calculations, with the exception that for the baselines, the concentration reported at time -1 week was combined with the time 0 duplicate measurement.

Statistical analysis was performed on each of the 11 variables by subtracting the combined baseline mean from the mean at 3,6, and 9 months. These changes were then further studied by the analysis of variance in order to test the significance between the effects of treatments, the 3-monthly periods of treatment, the 6 different orders in which the treatments were given, and any possible interaction. The error variance derived from the analysis of variance was used to calculate linear comparisons between the mean changes brought about by the 3 diuretics, and to set confidence limits (Snedecor and Cochran, 1967).

Each patient was asked to state a preference for a particular diuretic after 6 and 9 months.

The study design was agreed by St Mary's Hospital Ethical Committee.

\section{Results}

All patients remained stable; there was no significant change in body weight during each 3-month period of treatment (Table 1), nor was there any significant change in body weight over the 9 months of the trial $(+1.43 \mathrm{~kg}$, n.s., paired $t$-test $)$. In no patient was it necessary to alter the dose of the diuretic. No patient reported any gastrointestinal upset which might have affected the plasma biochemical concentrations.

Table 1 shows the mean changes in the plasma biochemical variables during treatment with the 3 diuretics. It also shows an analysis of the statistical significance of the effects of treatments, the way in which patients were grouped into orders, the 3 consecutive 3-monthly periods and any possible interaction. A significant difference between the effects of the diuretic treatments was seen in the analysis of the potassium data. Table 1 also shows that by using the analysis of variance, it was possible to partition off the variation that occurred among patients grouped into orders for plasma sodium, bicarbonate, calcium and urea.

The details of the analysis of variance with respect to the potassium data are shown in Table 2. Since a significant difference was observed between treatments, it was appropriate to compare the changes in plasma potassium concentration brought about between pairs of diuretics and to set confidence limits (Table 3). Thus the difference between the changes in plasma potassium produced by bumetanide and bendrofluazide was $0.49 \mathrm{mmol} / 1$, with lower and upper confidence limit $(95 \%)$ of +0.12 and $+0.87 \mathrm{mmol} / 1$ respectively. This difference was statistically significant.

In terms of the absolute changes in plasma potassium shown in Table 1, as distinct from the mean differences between diuretics, bumetanide produced the smallest change $(+0.11 \mathrm{mmol} / 1$ with $95 \%$ confidence limits of -0.16 to +0.39 ) and bendrofluazide the greatest change $(-0.38 \mathrm{mmol} / 1$ with $95 \%$ confidence limits of -0.66 to $-0 \cdot 10$ ). Frusemide pro-

TABLE 1. Mean changes brought about by the 3 diuretics. The significance levels are calculated from the analysis of variance used to investigate how changes were related to the effects of treatments; the way in which patients were grouped into 'orders'; the 3 consecutive 3-monthly periods and any interaction between these effects

\begin{tabular}{|c|c|c|c|c|c|c|c|}
\hline & \multicolumn{3}{|c|}{ Mean changes brought about by } & \multicolumn{4}{|c|}{ Statistical significance of the effects of } \\
\hline & $\begin{array}{c}\text { Bendrofluazide } \\
\text { (A) }\end{array}$ & $\begin{array}{l}\text { Bumetanide } \\
\text { (B) }\end{array}$ & $\begin{array}{l}\text { Frusemide } \\
\text { (C) }\end{array}$ & Treatments & Orders & Periods & Interaction \\
\hline $\begin{array}{l}\text { Body weight }(\mathrm{kg}) \\
\text { Sodium }(\mathrm{mmol} / \mathrm{l}) \\
\text { Potassium }(\mathrm{mmol} / \mathrm{l}) \\
\text { Bicarbonate }(\mathrm{mmol} / \mathrm{l}) \\
\text { Magnesium }(\mathrm{mmol} / \mathrm{l}) \\
\text { Calcium }(\mathrm{mmol} / \mathrm{l}) \\
\text { Glucose }(\mathrm{mmol} / \mathrm{l}) \\
\text { Creatinine }(\mu \mathrm{mol} / \mathrm{l}) \\
\text { Urea }(\mathrm{mmol} / \mathrm{l}) \\
\text { Urate }(\mu \mathrm{mol} / \mathrm{l}) \\
\text { Cholesterol }(\mathrm{mmol} / \mathrm{l})\end{array}$ & $\begin{array}{l}+0.47 \\
-0.18 \\
-0.38 \\
+2.83 \\
-0.04 \\
-0.01 \\
+0.36 \\
+3.30 \\
+0.34 \\
+0.03 \\
-0.13\end{array}$ & $\begin{array}{r}+0.47 \\
+0.93 \\
+0.11 \\
+1.25 \\
0.00 \\
-0.02 \\
+0.42 \\
+4.55 \\
+0.72 \\
+0.24 \\
-0.25\end{array}$ & $\begin{array}{r}+0.70 \\
+1.06 \\
-0.24 \\
+2.14 \\
0.00 \\
-0.04 \\
-0.07 \\
+3.00 \\
+0.31 \\
-0.01 \\
-0.34\end{array}$ & $\begin{array}{l}\text { n.s. } \\
\text { n.s. } \\
P<0.05 \\
\text { n.s. } \\
\text { n.s. } \\
\text { n.s. } \\
\text { n.s. } \\
\text { n.s. } \\
\text { n.s. } \\
\text { n.s. } \\
\text { n.s. }\end{array}$ & $\begin{array}{c}\text { n.s. } \\
P<0.01 \\
\text { n.s. } \\
P<0.02 \\
\text { n.s. } \\
P<0.02 \\
\text { n.s. } \\
\text { n.s. } \\
P<0.02 \\
\text { n.s. } \\
\text { n.s. }\end{array}$ & $\begin{array}{l}\text { n.s. } \\
\text { n.s. } \\
\text { n.s. } \\
\text { n.s. } \\
\text { n.s. } \\
\text { n.s. } \\
\text { n.s. } \\
\text { n.s. } \\
\text { n.s. } \\
\text { n.s. } \\
\text { n.s. }\end{array}$ & $\begin{array}{l}\text { n.s. } \\
\text { n.s. } \\
\text { n.s. } \\
\text { n.s. } \\
\text { n.s. } \\
\text { n.s. } \\
\text { n.s. } \\
\text { n.s. } \\
\text { n.s. } \\
\text { n.s. } \\
\text { n.s. }\end{array}$ \\
\hline
\end{tabular}

n.s. $=P>0.05$. 
TABLE 2. Analysis of variance for potassium data

\begin{tabular}{lcccc}
\hline Source of variation & Sum of squares & d.f. & Mean square & Variance ratio \\
\hline Treatments & 2.3805 & 2 & $1 \cdot 1903$ & 3.74 \\
Between subjects within orders & 0.5818 & 5 & $0 \cdot 1163$ & \\
Between periods & 0.3406 & 2 & $0 \cdot 1703$ & \\
Interaction & 1.7527 & 10 & $0 \cdot 1753$ & \\
Error & 10.8293 & 34 & 0.3185 & \\
Total & $15 \cdot 8851$ & & & \\
\hline
\end{tabular}

TABLE 3. Comparison between the changes in plasma potassium concentration produced by pairs of diuretics

\begin{tabular}{lccc}
\hline & $\begin{array}{c}\text { Frusemide- } \\
\text { Bendrofluazide }\end{array}$ & $\begin{array}{c}\text { Bumetanide- } \\
\text { Frusemide }\end{array}$ & $\begin{array}{c}\text { Bumetanide- } \\
\text { Bendrofluazide }\end{array}$ \\
\hline $\begin{array}{l}\text { Differences } \\
\text { (mmol/l) }\end{array}$ & $0.14^{*}$ & 0.36 & 0.49 \\
Confidence & $\begin{array}{ccc}-0.24 \\
+0.51\end{array}$ & $\begin{array}{l}-0.01 \\
+0.74\end{array}$ & $\begin{array}{l}+0.12 \\
+0.87\end{array}$ \\
limits & 0.723 & 1.919 & 2.640 \\
$t$-value & n.s. & n.s. & $<0.02$ \\
\hline
\end{tabular}

* $0 \cdot 14=(-0 \cdot 38-(-0 \cdot 24))$. See Table 1 .

duced an intermediate effect $(-0.25 \mathrm{mmol} / \mathrm{l}$ with $95 \%$ confidence limits of -0.53 to +0.03 ).

Six patients developed hypokalaemia (plasma potassium $<3.5 \mathrm{mmol} / \mathrm{l}$ ) during the trial: 4 on bendrofluazide and 2 on frusemide. Plasma potassium returned to normal in one patient during the subsequent 3-month period on frusemide and in 3 patients during the period on bumetanide. Hypokalaemia did not occur during treatment with bumetanide.

There was no marked patient preference for either thiazide or loop diuretic. Seven preferred the slow diuresis of the thiazide, while 7 preferred the short action of the loop diuretics. Four expressed no preference.

\section{Discussion}

This trial suggests that the 3 diuretics differ in their capacity to produce changes in plasma potassium concentrations in elderly patients requiring long-term treatment for cardiac oedema. There are theoretical reasons why loop and thiazide diuretics should differ in this respect. Urinary potassium excretion may be related to carbonic anhydrase inhibitory activity (Ramsay et al., 1978). Such inhibition is greater for thiazides than for frusemide, and is marginally greater for frusemide than for bumetanide (Puschett and Rastegar, 1974; Lant, 1975). The propensity of a diuretic to produce hypokalaemia may be related also to its duration of action, the longer acting ones allowing proportionately less time for compensatory renal potassium retention. This hypothesis may explain apparent, although statistically non-significant differences between the action of the 2 loop diuretics on plasma potassium concentrations. The duration of action of bumetanide is marginally shorter than that of frusemide (Bennion-Pedley et al., 1975), so that disturbances in potassium homoeostasis should be less likely to occur.

This study can be criticized on the grounds that plasma potassium and not total body potassium was measured, and that plasma potassium is not necessarily related directly to total body potassium (Edmonds and Jasani, 1972). In clinical practice, nevertheless, plasma potassium, not total body potassium, is routinely used as the guide to the need for potassium supplements or a potassium-sparing drug.

The study provides no support for other differences that have been attributed to loop and thiazide diuretics. There was no apparent effect on calcium, lipid, urate or glucose metabolism. This may be related to the short duration of the study, and to the fact that non-fasting blood samples were taken.

These findings raise the question whether potassium supplements are required during long-term use of diuretics. The need for potassium supplements or potassium-sparing drugs appears to be less when using loop diuretics than when using thiazides. However, this is a small study and the risk of hypokalaemia cannot be excluded during treatment with loop diuretics when a much larger population is considered. Even with bumetanide, which appears to be the least likely to produce hypokalaemia, potassium supplements may be required during long-term treatment.

\section{Acknowledgment}

We would like to thank Mr P. N. Underwood of Leo Laboratories Ltd for assistance in the design and analysis of this study.

\section{References}

Bennion-Pedley, J., Postlethwaite, D.L., Lomas, D.M. \& DoNALD, J.F. (1975) The effect of bumetanide and frusemide on frequency of micturition. Journal of International Medical Research, 3, 241.

Davies, D.L., Lant, A.F., Millard, N.R., Smith, A.J., WARD, J.W. \& WILSON, G.M. (1974) Renal action, therapeutic use and pharmacokinetics of the diuretic bumetanide. Clinical Pharmacology, 15, 141. 
Dollery, C.T. (1973) Diabetogenic effect of the long-term diuretic therapy. In: Modern Diuretic Therapy (Ed by Lant, A.F. \& Wilson, G.M.), p. 320. Excerpta Medica, Amsterdam.

Duchin, K.L. \& Hutcheon, D. (1976) Comparison of bumetanide and hydrochlorothiazide on renal electrolyte excretion. Clinical Research, 24, 508A.

Dunn, F.G., KerR, I.C., McQueen, M.J. \& Thomson, R.M. (1975) Comparison of intravenous bumetanide and frusemide during open heart surgery. Postgraduate Medical Journal, 51, (Suppl. 6), 72.

EDmonds, C.J. \& JASANI, B. (1972) Total body potassium in hypertensive patients during prolonged diuretic therapy. Lancet, ii, 8.

Eknoyan, G., Suki, W. \& Martinez-Maldonado, M. (1970) Effect of diuretics on urinary excretion of phosphate, calcium and magnesium in thyroparathyroidectomised dogs. Journal of Laboratory and Clinical Medicine, 76, 257.

EdITORIAL (1975) Calcium, magnesium and diuretics. British Medical Journal, 1, 170.

LANT, A.F. (1975) Effects of bumetanide on cation and anion transport. Postgraduate Medical Journal, 51 (Suppl. 6), 35 .

Morgan, D.B. \& Davidson, C. (1980) Hypokalaemia and diuretics: analysis of publications. British Medical Journal, $1,905$.

PAK, C. (1973) Hydrochlorothiazide therapy in nephrolithiasis. Effect on the urinary activity product and formation product of brushite. Clinical Pharmacology and $\bar{\oplus}$ Therapeutics, 14, 209.

PlayfaIR, A.S. (1975) Picking a diuretic (letter). British Medical Journal, 3, 42.

Puschet,, J.B. \& Rastegar, A. (1974) Comparative study of the effects of metolazone and other diuretics on potassium excretion. Clinical Pharmacology and Therapeutics, 15, 397.

Ramsay, L.E., Mcinnes, G.T., Hettiarachi, J., Shelton, J. \& ScotT, P. (1978) Bumetanide and frusemide. A comparison of dose-response curves in healthy men. British Journal of Clinical Pharmacology, 5, 243.

SNEdecor, G.W. \& Cochran, W.G. (1967) Statistical Methods, p. 268. Iowa State University Press, Ames, Iowa.

WATT, D.A.L. (1978) Diuretics in the elderly (leter). British Medical Journal, 1, 1417.

WyngaARden, J. \& Kelly, W. (1978) In: The Metabolic Basis of Inherited Disease, 4th Edn (Ed by Stanbury, J., Wyngaarden, J. \& Frederickson, D.), p. 916. McGraw-Hill, Inc., New York. 